\section{idenotiune}

Jurnal Kajian Manajemen Dakwah

\title{
Jejak-Jejak Dakwah Budaya : Konversi Agama Massal di Asia Tenggara abad XV-XVII
}

\author{
Jarir Amrun ${ }^{1}$, Khairiah ${ }^{2}$ \\ ${ }^{1}$ Sekolah Tinggi Agama Islam Negeri Bengkalis \\ ${ }^{2}$ Universitas Islam Negeri Sultan Syarif Kasim Riau \\ Email: jarir@kampusmelayu.ac.id
}

\begin{abstract}
This article deals with cultural da'wah traces of religious conversion in the archipelago of the XV, XVI and XVII centuries. It is considered to be a form of inter-religious rivalry in the archipelago that is softly. Millions of people in the archipelago have converted to Islam without war, without destroying existing candid structures and traditions. It is interesting to study, it turns out that the preaching pattern carried out by previous scholars with a cultural approach was considered an ideal pattern. Culture is a field space for inter-religious dialogue. Wali Songo and previous archipelago scholars have proven that religious rivalries do not have to hate and despise each other.
\end{abstract}

Keywords: Conversion, Archipelago, Religious.

Abstrak: Artikel ini membahas tentang jejak-jejak dakwah dalam konteks konversi agama di nusantara abad XV, XVI dan XVII. Ia dianggap salah satu bentuk rivalitas antar-agama di nusantara yang lembut. Jutaan manusia di nusantara beralih ke agama Islam tanpa perang, tanpa merusak bangunan candi dan tradisi yang ada. Ini menarik dikaji, ternyata pola dakwah yang dilakukan para ulama terdahulu dengan pendekatan kebudayaan dianggap pola yang ideal. Kebudayaan merupakan ruang lapang untuk dialog antar-umat beragama. Wali Songo dan ulama nusantara terdahulu, telah membuktikan bahwa rivalitas beragama itu tidak harus saling membenci dan merendah yang lain.

Kata kunci: Konversi, Agama, Nusantara

\section{Pendahuluan}

Banyak pandangan bahwa masyarakat Asia Tenggara dipengaruhi agama Hindu dan Budha, buktinya raja-raja awal di Asia Tenggara umumnya beragama Hindu, ini terlihat dari namanama dan pola penyembahan pada binatang dan dewa lainnya dalam ajaran Hindu. Beberapa arca, patung, candi dan prasastri berbentuk binatang, dan benda lainnya (Khairiah, 2018, h.61-65).

Mulawarman, raja di Kutai, diindikasikan beragama Hindu. Taruma Negara sebagai sosok raja pertama di Pulau Jawa, menurut peninggalan arca bahwa beliau beragama Hindu. Di samping archa-archa yang bersifat kehinduan seperti arca ganesha, juga ditemukan acrcha Budha (Poesponegoro \& Notosusanto, 1993, h. 34). Namun ada pandangan bahwa agama Hindu dan Budha hanya kalangan raja dan bangsawan saja, sulit diterima masyarakat pada umumnya, apalagi dalam ajaran Hindu terdapat perbedaan kasta, tentunya menguntungkan raja, bangsawan, dan pendeta.

Ajaran agama yang sampai ke nusantara ini tentunya karena adanya hubungan perdagangan antara nusantara dengan India dan Cina. Pada gilirannya bukan hanya sebatas 
perdagangan, tetapi semua yang ada di India, termasuk kepercayaan, agama dan peradaban lainnya, masuk ke nusantara. DGE Hall menolak anggapan Hindunisasi, tetapi Indianisasi, artinya usaha meng-india-kan penduduk nusantara, namun akhirnya tidak berhasil. DGE Hall menyebutnya Indianisasi yang gagal di nusantara, yang belakangan disebut India Belakang. Kolonial Belanda menyebut Indonesia dengan sebutan Hindia-Belanda, artinya India yang dijajah Belanda. Demikian juga Cinaiasi, yakni usaha yang gagal men-cina-kan Asia Tenggara, maka disebutlah Indo-Cina (Hall, 1985, h. 5).

Pengaruh Hindu dan Budha ke nusantara karena secara geografis, para pedagang yang datang ke Asia Tenggara menggunakan angin monsoon. Maka Asia Tenggara disebut dengan Nanyang, negeri di bawah angin atau The Land Under the Wind (Amrun \& Khairiah, 2018, h. 126).

Memang perlu dibedakan antara Hindunisasi dengan Indianisasi. Jika Hindunisasi, adalah upaya menghindukan penduduk nusantara, sedangkan Indianisasi adalah usaha mengindia-kan penduduk nusantara dengan peradaban India. Namun karena agama Hindu itu asal mulanya dari India, maka sulit memisahkan antaranya kedua. Yang jelas pengaruh India terhadap Asia Tenggara sangat kuat. DGE Halla hanya ingin menjelaskan bahwa masyarakat Asia Tenggara itu berbeda dengan India dan Cina, makanya dia menyebut Indianisasi yang gagal. Masyarakat Asia Tenggara adalah rumpun tersendiri, baik dari sisi budaya, kepercayaan dan lainnya, berbeda dengan India, Cina dan Arab. Ajaran agama Hindu yang menerima realitas alam sebagai bagian kehidupan spiritual, maka muncul klaim generalisasi bahwa ajaran dinamisme dan animisme bagian dari ajaran Hindu.

\section{Metode}

Artikel ini menggunakan pendekatan sejarah. Pendekatan sejarah berguna untuk menjelaskan kejadian masa lampau secara kritis dengan perspektif masa kini. Data dalam artikel ini bersumber dari buku, artikel ilmiah atau dokumen yang relevan dengan topik atau tema yang akan dianalisis. Analisis terhadap data yang dikumpulkan menggunakan metode deskriptif. Analisis deskriptif berguna untuk menjelaskan peristiwa masa lampau secara koheren sesuai dengan focus kajian.

\section{Hasil dan Pembahasan}

\section{Konversi Agama di Nusantara}

Perubahan kepercayaan (konversi) agama, dari Hindu dan Budha besar-besaran (massal) di nusantara mengejutkan bangsa Barat, termasuk Spanyol dan Portugis, saat tiba di Nusantara. Ketika umat Islam di Spanyol habis diusir dengan cara inkuisisi, tetapi mereka melihat lain di Belahan Timur, yakni Asia Tenggara, ternyata agama Islam diterima di wilayah ini. Bahkan terjadi konversi agama besar-besaran, dari Hindu, Budha dan aliran kepercayaan ke Islam (Azra, 1999).

Ada anggapan Islam lebih mudah diterima secara umum (rakyat jelata sampai raja), karena Islam mengandung nilai-nilai igaliter, tidak ada kasta, tidak ada perbedaan antara raja, bangsawan dengan rakyat biasa. Padahal menurut teori hubungan dagang, antara Asia Tenggara dengan dunia lainnya, termasuk India dan Arab, sejak awal abad masehi ajaran 
agama lain sudah sampai, tetapi agama-agama sebelumnya terkesan ekslusif, hanya kalangan tertentu saja. Seperti agama Yahudi, mengapa tidak bisa diterima, karena hanya kalangan tertentu yang bisa masuk agama ini, makanya komunitasnya terbatas, di perkotaan dengan jumlah pengikut dari kalangan tertentu saja.

Islam sebagai agama rahmatan lil'alamin, rahmat bagi seluruh alam, tidak membedabedakan suku, bangsa dan derajat kebangsawanan seseorang. Pada awal kedatangan Islam, yang dibawa pedagang, karena jalur perdagangan adalah jalur hubungan pertama nusantara dengan dunia luar (peradaban India, Arab, Persia dan Cina). Kemudian para pedagang itu menikah, dan menetap beberapa saat, kemudian mereka kembali berdagang. Jalinan dengan pernikahan ini membuat pertalian hubungan darah dengan penduduk setempat.

Memasuki awal abad XIV, penyebaran Islam berkembang pesat. Jauh sebelum kedatangan bangsa Eropa (Portugis, Spanyol, Belanda, Inggris ke nusantara), sudah terjadi konversi agama di nusantara. Konversi agama digerakan oleh para wali Allah, dan ulamaulama besar di nusantara. Namun sejak kedatangan bangsa Eropa, kemudian muncul persaingan antara Islam dan Kristen yang berdampak semakin gencarnya konversi agama di nusantara.

Anthony Reid menyebutnya dengan revolusi agama, karena semakin gencarnya usaha untuk mengislamkan dan mengikristenkan wilayah Asia Tenggara. Kedatangan bangsa Barat, memunculkan perlawanan dari umat Islam (Reid, 1998, h. 175).

Usaha mengkristenkan penduduk Manila dan kepulauan sekitarnya adalah bentuk dari persaingan mempengaruhi wilayah nusantara. Bagian Filipina Selatan telah memeluk agama Islam terlebih dahulu, sementara wilayah Utara belum memeluk Islam (Majul, 1998, h. 18) . Antony Reid memetakan beberapa wilayah nusantara yang telah memeluk Islam dan sebagian lainnya yang kemudian dikristenkan oleh bangsa Barat.

Yang menarik perhatian bangsa Eropa, bahwa di Asia Tenggara telah terjadi konversi agama, dari Hindu-Budha ke Islam, jauh sebelum kedatangan mereka. Islam lebih mudah diterima, tanpa peperangan.

Sebelum kedatangan Bangsa Eropa, Wali Songo misalnya, mereka berhasil mengislamkan Pulau Jawa tanpa peperangan. Maulana Malik Ibrahim, sebagai guru besarnya atau grand syeikh para wali, berhasil mengubah kepercayaan masyarakat Jawa, dengan pendekatan yang lebih arif. Kultur Jawa yang kuat dengan kepercayaan dinamisme dan animisme, tentunya sulit ditembus, namun beliau bersama para wali lainnya berhasil memberi pencer ahan kepada masyarakat Jawa (Sofyan, et.al, 2000, h.7).

Anthony Reid memetakan Asia Tenggara saat Islam sudah menyebar, tetapi tidak memetakan awal-awal Islam sudah disebarkan oleh pedagang, ulama tasauf, dan pendekatan lainnya. Makanya, Anthony Reid memetakan beberapa wilayah saja di Asia Tenggara yang sudah Islam, pedalamannya belum. Padahal tahun 1347, Ibnu Batutah saat berkunjung ke Aceh, dia melihat orang Aceh sudah seluruhnya muslim da pengalaman agamanya cukup baik, bahkan Ibnu Batutah disambut dengan baik dan diberi bekal untuk melanjutkan perjalanan ke Cina. Selama dua pekan Ibnu Batutah menikmati sambutan Sulthan Aceh yang 
ramah, ini artinya waktu yang cukup lama untuk menjelaskan bagaimana kondisi umat Islam di Aceh saat itu.

Al-Malik Al-Zahir adalah pangeran di tempat itu (Aceh), merupakan pangeran keturunan ketiga dari penguasa-penguasa Kerajaan Aceh. Ia dengan hangat menyambut kedatangan Ibnu Batutah. Ia menghadiri Shalat Jumat dan pengajian tengah hukum syariat Ibnu Batutah memakai sarung (Dunn, 1995, h. 386).

Revolusi agama yang disebut Anthony Reid dikritik Azyumardi Azra, bahwa kata yang tepat adalah konversi agama di nusantara. Munculnya rivalitas antara Islam dan Kristen menimbulkan persaingan di Asia Tenggara, isu-isu di Timur Tengah akhirnya terbawa ke Asia Tenggara (Azra, 1999, h. 59). Rivalitas ini yang menyebabkan usaha islamisasi dan kristenisasi semakin gencar di nusantara. Azyumardi Azra menyebutnya, islamsasi tahap kedua, yakni masa perdagangan. Islmisasi tahap pertama pendekatan tasawuf, tahan kedua lebih pada rivalitas antara Islam dan Kristen, karena pengaruh dunia Arab yang juga mengalami pertentangan antara Islam dengan Kristen (bangsa Barat). Jika di tahap awal, islamisasi hanya di kota-kota pesisir, sepert di Selat Melaka dan sekitarnya (Amrun \& Khairiah, 2018, h.87). Tahap kedua ini memasuki ke wilayah pedalaman. Penduduk di pedalaman nusantara mulai mengenal Islam.

\section{Penyebaran Islam di Nusantara Abad XV dan XVI}

Ciri umum penduduk nusantara adalah sikap ramah dan menghormati pendatang, terbuka terhadap perubahan, dan menerima beragam budaya yang masuk, namun selalu saja, ada penyesuaian dengan kultur nusantara (akulturasi). Hal ini dibuktikan dengan adanya ulamaulama besar yang datang dari Arab dan sekitarnya (Hadramaut, Persia, Gujarat) yang diterima menjadi wali, sunan, ulama, di nusantara (Koentjaraningrat, 2002, 202).

Misalnya Maulana Malik Ibrahim yang dikenal sebagai Syeikh Magribi, dalam Bahasa Jawa dikenal Makdum Brahim Asmara. Menurut silsilah, beliau berasal dari keturunan Nabi Muhammad SAW, yakni Jumadil Qubro, Zaenal Khusain, Zaenal Kubra, Zaenal Alim, Zaenal Abidin, Syayyidian Hussein, Fatimah dan Nabi Muhammad SAW. Beliau punya strategi dakwah yang sederhana tetapi dirasakan langsung oleh masyarakat Pulau Jawa saat itu, yakni turun menemui penduduk Pulau Jawa, berdialog, diskusi, dan ikut menyelesaikan masalah yang dihadapi masyarakat saat itu (Syamsu, 1996, h. 49).

Misalnya saat kemarau panjang dialami penduduk Jawa Timur, Maulana Malik Ibrahim menyaksikan tradisi masyarakat setempat yang mengorbankan anak gadis untuk dijadikan persembahan, agar turun hujan. Maulana pun mencegah tradisi ini, dengan mengajar Shalat Istisqo, tanpa mengorbankan orang untuk menurunkan hujan. Alhadulillah dengan izin Allah hujan pun turun. Maka berbondong-bondong orang Jawa ingin belajar tentang Islam (masuk islam) (Sofwan, 2000, h. 28).

Kekuatan batin yang dimiliki Syeikh Maulana Malik Ibrahim diuji olah para jawara di Jawa, dan melalui "dialog mistis" pola seperti inilah islamisasi terjadi di Jawa. Seperti dalam kisah pertemuan Syaikh Maulana Malik Ibrahim dengan gerombolan perompak di suatu desa. Dengan kekuatan spiritual, Syeikh Maulana berhasil mengalahkan ketua gerombolan penjahat (Tekuk Penjalin) tanpa kekerasan, ini yang menyebabkan kelompok pejahat itu simpati dengan sikap Maulana yang arif, bahkan penduduk desa pun ikut memeluk Islam. 
Demikian juga wali-wali lainnya, mereka memiliki kharisma di mata umat, baik masyarakat yang sudah memeluk ajaran Islam maupun yang belum. Yang namanya wali itu banyak karomahnya. Kepercayaan masyarakat terhadap wali ini berdampak pada proses dakwah para wali di kalangan masyarakat Jawa saat itu. Dalam istilah kini disebut dengan strategi kebudayaan, bahwa budaya itu merupakan wahana untuk menjelaskan tentang konsep, ajaran, agama. Wali Songo berhasil menggunakan strategi kebudayaan (Murtopo, 1971, h. 67).

Sugesti masyarakat muncul karena kharimastik para wali. Bahasa Koentjaraningrat, bahwa masyarakat tradisional itu percayaan kepada keramat (karomah) (Koenjtaraningrat, 2002, h. 203). Kharima para wali karena mereka meneladani Rasulullah dalam berdakwah, yakni turun langsung di tengah masyarakat jahiliah (belum paham Islam). Para wali mengajak komunitas masyarakat Jawa memeluk Islam dengan memanfaatkan apa yang dimilikinya.

Kesaktian Wali Songo bersumber pada Alquran dan Hadis, kesaktian itu sendiri merupakan sarana untuk menjelaskan tentang ajaran Islam. Bagi masyarakat Jawa klasik yang cenderung senkritis, tentunya kesaktian, mandraguna saat itu merupakan sesuatu yang sangat diharapkan dan diidam-idamkan. Makanya banyak yang berguru kepada para wali tersebut. Namun para wali tetap menjaga ajarannya dengan koridor ajaran tauhid, Alquran dan Hadist.

Misalnya Sunan Kalijaga dengan sensasi gemalan sekaten dan saka tatal di Masjid Demak. Yakni menciptakan tiang yang disusun dari tatal-tatal kecil yang berserakan. Semua dilakukan Sunan Kalijaga dalam tempo satu malam.

Muncul pula Sunan Bonan yang berhasil melahirkan tembang-tembang yang bisa menghipnotis masyarakat Jawa saat itu, yang cenderung pada tembang. Kalau sekarang seperti kecenderungan remaja kepada K Pop (Korea Pop). Tembang-tembang Sunan Bonan ini bersumber pada ajaran Islam, Alquran dan Hadist. Salah satu tembang yang popular dan dipopulerkan kembali oleh penyanyi Ofik, yakni Tombo Hati (Obat Hati). Yakni tembang yang bersumber pada Surat Al-Mu'minun.

Strategi dakwah Wali Songo adalah strategi kebudayaan. Mereka menilai budaya adalah hasil akal budi dan merupakan sarana untuk mengislamkan masyarakat Jawa ketika itu. Para wali tidak membenturkan budaya dengan agama, budaya sebagai hasil karya budi manusia, yang bersifat netral, agamalah yang memandunya kepada yang baik. Ibarat pisau, bisa digunakan untuk membunuh, tetapi juga bisa digunakan untuk memasak di dapur. Tergantung pada orang yang menggunakannya. Para wali memberi nilai agama pada budaya, seperti Sunan Kalijaga yang berhasil mewarnai wayang dengan nilai-nilai Islam. Kalamatusyahadah (kalimat tauhid) dimasukkan ke dalam wayang, sebagai pembukaan. Artinya kalimat syahadat (Asyahadu alla ilahaillallah wa asyahadu anna Muhammad Rasulullah) adalah gerbang untuk memasuki Islam.

Strategi kebudayaan yang digunakan para wali terbukti ampuh dan berhasil mengislamkan jutaan umat manusia di Nusantara. Ahli fiqh saja tidak cukup untuk menjadi pendakwah, tetapi perlu ahli tauhid, dakwah bilhikmah, melihat kebudayaan itu sebagai 
sarana yang pas untuk menyampaikan nilai-nilai Islam ke masyarakat yang terbelakang. Pola ini sangat baik dalam menghindari konflik agama (Amrun, 2018, h. 109).

Tanpa peperangan, tanpa menghancurkan candi, dan rumah ibadah masyarakat Jawa yang saat itu beragama animisme, dinamisme, Hindu dan Budha. Mereka berhasil mengislamkan masyarakat Nusantara tanpa konflik fisik (perang) sepertinya ekspansi Islam di Timur Tengah. Sungguh mereka (para wali) mengamalkan apa yang telah diajarkan Nabi Muhammad SAW, bahwa dakwah bilhikmah itu jauh lebih baik dibandingkan peperangan.

Secara pribadi, masing-masing para wali ini memiliki watak yang khas, masingmasing berbeda dan memiliki karakter yang sulit disatukan. Namun di sisi lain, mereka memiliki kesatuan (kesamaan pandangan) yakni nilai tauhid, dan ajaran tasauf yang muktabar, yakni ahlusunnah waljamaah. Hal ini terlihat saat terjadi penyimpangan yang dilakukan Syeikh Siti Jenar, aliran wihdatulwujud, spontan para wali menggelar ijtimak, dan memutuskan bahwa Syeik Siti Jenar itu sesat.

Strategi dakwah kebudayaan yang dilakukan para wali ini sangat longgar dalam hal menerima perbedaan budaya, tetapi dalam hal perbedaan aliran tasauf (tauhdi) mereka sangat ketat. Mereka menjaga agar nilai tauhid di kalangan umat Islam tidak menyimpang. Sunggu keliru bahwa wali songo jika disebut Wali Songo membiarkan penyimpangan tauhid, mereka sangat ketat. Longgar di budaya, tetapi ketat (tajam) di tauhid.

Masing-masing wali memiliki peran penting, dalam proses Islamisasi Jawa. Budaya lokal bukan ancaman, kalaupun ada nilai kesyirikan, para wali mengubahnya kea rah tauhid Islam. Misalnya doa-doa yang biasa digunakan leluhur orang Sunda saat membuka hutan, diubah menjadi doa-doa yang terkandung di dalamnya nilai-nilai tauhid. Bagi masyarakat Sunda, setiap aktivitas pertanian, mulai dari membuka lahan, menanam, panen, semua ada jampi-jampi dalam bahasa Sunda. Jampi-jampi itu dihapus oleh Sunan Gunung Jati tetapi dimasukkan nilai-nilai Islam (Sunardjo, 1983, h. 50). Bukan hanya dalam hal bertani, juga bertenak, mengobati orang sakit, jampi menghadapi orang jahat dan segala aktivitas manusia dari hamil, lahir, remaja (baligh) sunat, menikah, sampai meninggal, semua diubah oleh Sunan Gunung Jati. Rasa rindu kehadiran akan sosok wali di tengah masyarakat Sunda terobati, sekaligus tidak menghilangkan tradisi lelulur mereka (Saksono, 1998, h. 108).

Sunan Gresik mengubah motif kain batik kepada bentuk yang dibolehkan olah Islam. Sunan Ampel menyusun aturan-aturan syariat bagi orang Jawa. Jika selama ini banyak yang belum menutup aurat, maka secara berangsur masyarakat Jawa pun menutup auratnya, khususnya saat melaksanakan shalat lima waktu.

Sunan Giri mengubah perhitungan Jawa, hari, bulan, tahun, windu dan masa. Mengubah nama-nama hari dan waktu merupakan pekerjaan berat, namun Sunan Giri berhasil mengubahnya, tanpa terasa masyarakat Jawa pun ikut menerima, dan merasa tidak ada yang berubah dari sebelum Islam dan setelah Islam. Sunan Giri berhasil secara halus mengubah budaya waktu dengan pendekatan budaya.

Sunan Bonang, sebagai sosok wali yang ahli di bidang sastra, dia berhasil melahirkan tembang-tembang jawa yang bersumberkan Alquran dan Hadits. Bersama Sunan Kali Kaga, Sunan Bonang pun pun mengisi kehausan akan tembang dan gending Jawa. Mereka wali 
yang produktif, melahirkan tembang dan gending fenomenal, hingga kini masih dirasakan masyarakat Jawa.

Dalam hal pendidikan juga para wali ini mengedepankan strategi kebudayaan, misalnya pesantren yang tidak ada dalam khazanah Islam di Arab, mereka mengadopsi pola pendidikan mandala-mandala Hindu dan Budha, yakni pola pendidikan tradisional yang sudah ada sebelum Islam datang. Kata santri sendiri berasal dari Shastri, bahasa sansekerta yakni artinya mereka yang memahami buku-buku agama (Hindu) (Sunyoto, 1990, h. 46). Banyak kata-kata yang diadopsi dari Bahasa Sansekerta, seperti sembahyang untuk menyebutkan shalat. Kata sembahyang berarti menyembah eyang (nenek moyang). Kadang sangat sulit diterima bagaimana para wali yang menguasai Bahasa Arab itu menerima kata tersebut, tetapi itulah strategi dakwah melalui kebudayan, mengisi nilai-nilai Islam pada budaya Jawa itu, dianggap oleh para wali saat itu lah strategi dakwah yang pas. Ada juga istilah Langgar yang digunakan orang Jawa untuk menyebutkan mushala (tempat shalat). Langgar berasal dari kata Sanggar, tempat berkumpul.

Dari sisi strategi dan organisasi dakwah, terkesan para wali ini merupakan suatu organisasi yang terencana dengan baik. Masing-masing daerah memiliki wali. Mulai dari Jawa Barat sampai ujung Jawa Timur. Basis mereka sangat kuat, dan mengakar sampai ke akar rumput massa. Pusat mereka pun (Demak) posisinya pas di tengah-tengah Pulau Jawa. Jadi sulit dikatakan jika Wali Songo ini bukan merupakan dakwah yang tidak terorganisasi. Mereka memiliki strategi jitu dan organisasi yang kuat. Bahkan mereka memiliki jaringan sampai ke Champa (Vietnam), Melaka, Aceh, India, Persia, Yaman dan tentunya Makkah dan Madinah (Haramain). Pola ini yang kemudian diteruskan oleh ulama-ulama Nusantara, dalam bentuk jaringan ulama nusantara, sebagaimana disebut Azyumardi Azra (1994, h. 75).

Mualana Malik Ibrahim, yang dikenal sebagai grand syeikhnya para wali, adalah tokoh yang sudah melanglang buana, dari Makkah, Aceh, Palembang dan Jawa. Begitu Fatahillah, yang juga sudah melanglang buana ke Makkah, Aceh, Melaka dan tentunya Jawa. Para wali ini memiliki jaringan yang kuat ke sumber utama ajaran islam, yakni Makkah. Makanya ketika Syeikh Siti Jenar mengenalkan wihdatul wujud, para wali menyadari bahwa apa yang dilakukan Syeikh Siti Jenar itu menyimpang. Fenomena ini ada di Timur Tengah, bahwa Ibnu Arabi dengan ajaran wujudiahnya itu dianggap menyimpang, dan tentunya sampai ke telinga para wali di nusantara.

Para wali itu bukan sosok yang terisolir dari dunia internasional, mereka merupakan sosok yang dalam ilmu agamanya, dan juga memiliki pergaulan yang luas. Mereka berhasil mengubah wawasan agamanya yang luas dan dalam, (menguasai bahasa Arab, Melayu, dan Jawa), juga berhasil mengeksekusi dalam bentuk praktik di lapangan. Misalnya sosok Sunan Bonang, yang menguasai Alquran dan Hadits, dia berhasil memasukkan nilai-nilai Islam ke dalam tembang jawa yang trendi saat itu.

Bukti bahwa para wali itu memiliki organisasi yang kuat, mereka sering menggelar pertemuan, membahas masalah umat terutama masalah yang dianggap urgen. Murid-murid para wali ini pun diturunkan ke penjuru wilayah di Jawa, bahkan mereka dirikim ke wilayah terpencil. Misalnya putra Raden Rahmad, yakni Raden Hamzah dikirim ke Tumapel. Raden Makdum Ibrahim dikirim ke Kahuripan. Syeikh Maulana Ishak dikirim ke Pasuruan menikah 
dengan Rarasatari, putri Bupati Pasuruan. Raden Hasan ditempatkan ke Glagah Wangi Bintara, termasuk wilayah Lasem, menggantikan kakeknya, Syeikh Bentong. Raden Husin, saudara seibu Raden Hasan (anak Arya Damar) ditempatkan di ibu kota Majapahit. Usman Haji ditempatkan di Ngundung. Syeikh Suta Maharaja ditempatkan di Pajang. Raden Ainul Yaqin, putra Maulana Ishak ditempatkan di Giri. Syeikh Maulana Ishak, kabarnya dia kembali ke Pasai (Aceh), ini mengindikasikan bahwa jaringan ulama Jawa dengan Aceh dan India, Persia, Haramain sudah terjalin kuat saat itu. Formasi penempatan para wali pun kadang mengalami perubahan, misalnya Raden Makdum Ibrahim yang semula dikirim ke Daha, kemudian dipindahkan ke Kadipaten Tuban, daerah Bonang. Radan Makdum Ibrahim dibantu santrinya, Raden Syahid (Sunan Kali Jaga) putra Bupati Tuban. Demikian Raden Hamza yang semula dikirim ke Tumapel kemudian ditarik ke pesisir, yakni Lamongan, dengan gelar Pangeran Lamongan (Sunyoto, 1990, h. 77).

Strategi Wali Songo inilah yang kemudian dipelajari orientalis yang datang kemudian ke nusantara. Mereka heran, mengapa bisa para wali dan ulama tasuaf di nusantara ini melakukan konversi (pindah) agama ke Islam, tanpa peperangan. Kedatangan bangsa Eropa pada abad XVI tidak banyak mengubah pola strategi dakwah yang dilakukan ulama di nusantara, tetapi malah memberi semangat untuk berjihad, inilah yang kemudian disebut oleh Anthony Reid revolusi agama di Asia Tenggara.

\section{Konversi Agama di Nusantara pada Abad XVII}

Pola islamisasi memasuki Abad XVII merupakan kelanjutan pola yang telah dibangun Wali Songo. Azyumardi Azra menggambarkan jaringan ulama nusantara semakin luas, dan semakin dekat hubungan antara Nusantara dengan Timur Tengah. Namun stategi dakwan dan muatannya berbeda. Jika pada tahap awal lebih menekankan pendekatan tasauf falsafi, tahap berikutnya pendekatan tasauf syar'i. Jaringan ulama tidak lagi regional, tetapi internasional (Hajjaj, 2011, h. 17).

Kedatangan Nuruddin Arraniry, yang berasal dari Kota Ranir di India, ke Pasai (Aceh) membuktikan jaringan ulama nusantara semakin meluas. Tidak lagi pengiriman ulama dari Pasai ke Jawa, tetapi ulama Pasai didatangkan dari India. Nuruddin bukan penduduk asli Aceh, tetapi asli dari India, namun beliau tidak hanya menguasai Bahasa Arab, Urdu dan Persia, tetapi juga bahasa Melayu yang menjadi lingua pranca bahasa di nusantara.

Sebelum kedatangan Nuruddin, di Aceh sudah muncul ulama besar, Hamzah Fansuri, yang beraliran wujudiah. Apa yang disampaikan Hamzah Fansuri ini dianggap membayakan akidah umat, maka Nuruddin pun datang ke Aceh.

Hamzah Fansuri yang merupakan ulama lokal, yang berasal dari Fansur, sekarang Pancur, Barus, Tapanuli Tengah, memiliki pengetahuan yang luas dan tentunya mengenal dunia Timur Tengah, termasuk Persia dengan baik. Ketika di Bagdad muncul ulama besar Ibnu Araby yang membawa pemikiran wujudiah, pengaruhnya sampai ke nusantara, termasuk salah seorang ulamanya adalah Hamzar Fansuri (1602) (Azra, 1995, h. 78).

Perbedaan pemahanan tasauf antara Hamzar Fansuri dengan Nur ruddin Arraniry menunjukkan bahwa pada abad XVI penganut agama Islam sudah ghalib (banyak) di Aceh. Ilmu agam sudah berkembang pesat, Aceh sebagai pusat penyiaran Islam. Ketika Kerajaan Aceh Darussalam menaklukkan pesisir Sumatera Utara, bahkan sampai ke Riau, maka syiar 
Islam pun sampai ke wilayah tersebut. Abad XVI adalah proses islamisasi wilayah Sumatera Tengah (pesisir Sumatera dan pedalamannya).

Demikian juga Syamsuddin Al-Sumatrani (1630), ada yang menyebutnya adalah rekan Hamzah Fansuri, tetapi banyak yang menyebutnya murid Hamzah Fansuri. Azyurmardi Azra menyebutnya dua tokoh ini sebagai ulama tasauf falsafi, yang kemudian disusul oleh ulama-ulama tasauf syar'I dan kelompok baru inilah yang menghubungknan ulama-ulama nusantara dengan Timur Tengah. Yakni Syeikh Yusuf Al-Makasari dan Abdurrauf Al-Sinkli. Mereka merupakan tokoh yang menghubungkan jaringan ulama internasional dengan ulama regional (Azra, 1999, h. 135).

Jaringan ulama ini merupakan strategi dakwah dalam mengislamkan masyarakat nusantara. Mereka memberi pendidikan akidah, tauhid, dan juga syariah yang lebih luas, sehingga masyarakat di nusantara ini mengenal kitab-kitab fiqh muktabarah, sehingga bukan hanya secara akidah saja mereka kuat, tetapi juga praktik ibadahnya benar. Ini proses pembaharuan awal yang dilakukan di wilayah nusantara. Proses pembaharuan tahap kedua, yakni munculnya gerakan padri di nusantara (Kartodirjo, 1993, h. 377).

Dari gambaran tentang stategi dakwah ulama abad XV dan XVI, maka tergambar konversi agama massal abad XV dan XVI dianggap lebih berhasil karena para ulama bisa melakukan dialog lintas agama, dengan pendekatan humanisme, nilai-nilai kemanusian. Para ulama ikut memecahkan masalah yang dihadapi masyarakat lokal sehari-hari, bukan hanya masalah tauhid, tetapi masalah praktik kehidupan. Namun setiap masa memiliki keunikan tersendiri, strategi ulama pada abad XVII berhasil membangun kesadaran baru bahwa umat Islam di nusantara memiliki saudara di beberapa belahan dunia. Para ulama di belahan dunia lainnya ikut mencerdaskan umat Islam di nusantara. Kesadaran baru akan persamaan penderitaan dijajah, sehingga pada gilirannya munculnya perlawanan terhadap penjajah, yakni perang fi sabilllah, bagi masyarakat Aceh dikenal dengan perang sabi' (Alfian, 1987, h. 105).

Pendekatan ketuhanan (akidah) dianggap ruang yang lapang dalam berdialog dengan masyarakat nusantara ketika itu (Andito, 1998). Para wali songo ini tidak menjelek-jelekkan apa yang diyakini (disembah) masyarakat Jawa, tetapi secara perlahan diajak berubah, bahkan para wali itu menggunakan sarana budaya untuk menyampaikan pesan-pesan Islam. Secara persuasif para wali mengajak masyarakat tempatan untuk beralih ke ajaran Islam.

\section{Simpulan}

Konversi agama massal di nusantara terjadi pada abad XV, XVI dan XVII berlangsung damai, tidak merusak candi, menyalahkan tradisi yang ada, bahkan tanpa peperangan. Strategi dakwah di nusantara melalui pendekatan budaya, sebagaimana dilakukan ulamaulama perintis dakwah di nusantara seperti wali songo di Jawa merupakan model moderasi beragama yang layak dicontoh ke depan di negeri ini. Pola beragama ini di kemudian hari mengalami reduksi. Yakni dari pola tasawuf falsafi, berubah menjadi tasawuf amaly sunni, kemudian pada dekade berikutnya gerakan pemurnian (padri), yang menimbulkan konflik antara kaum adat dengan padri. 


\section{Referensi}

Alfian, Ibrahim.(1987). Perang di Jalan Allah, Cetakan I. Jakarta: PT New Aqua Press.

Amrun, Jarir,. \& Khairiah.(2018). Sejarah Nusantara: Perpsektif Geologis, Zoologis dan Etnografis, Nusantara: Journal for Southeast Islamic Studies, Volume I4. h. 126-130.

Amrun, Jarir,.\& Khairiah.(2018). Meneliti Situs-Situs Awal Peradaban di Pulau Bengkalis, Akademia, Vol 14, h. 85-105.

Amrun, Jarir. (2018). Solusi Konflik Agama di Media Sosial, Toleransi, Vol 10, No.2, h. $108-118$.

Andito (Ed).(1998). Atas Nama Agama, Wacana Agama dalam Dialog Bebas Konflik, Cetakan I. Jakarta: Pustaka Hidayah.

Azra, Azyumardi.(1994). Jaringan Ulama Timur Tengah dan Kepulauan Nusantara Abad XVII dan XVIII (Melacak Akar-akar Pembaharuan Pemikiran Islam di Indonesia). Bandung: Mizan.

Azra, Azyumardi.(1999). Renaisans Islam Asia Tenggara. Bandung: Remaja Rosda Karya.

Dunn, R.E.(1995). Petualangan Ibnu Batutah (Seorang Musafir Abad XIV). Jakarta: Yayasan Obor.

Ecole D'extreme Orient.(1981). Kerajaan Campa, Cetakan I. Jakarta: PN Balai Pustaka.

Graaf, H.J. dkk. (1984). Cina Muslim di Jawa Abad XV dan XVI Antara Historisitas dan Mitos. Jogjakarta: PT Tiara Wacana Yogya.

Hajjaj, Muhammad Fauqi.(2011). Tasauf Islam dan Akhlak (Tashawwuf Al-Islami wal AlAkhlaq), Cetakan I. Jakarta: Amzah.

Hall, D.G.E.(1985). Sejarah Asia Tenggara.Surabaya: PT Usaha Nasional.

Kartodirdjo, Sartono.(1993). Pengantar Sejarah Indonesia Baru: 1500-1900, Dari Emporium sampai Imperium, Jilid I, Cetakan IV. Jakarta: PT Gramedia Pustaka Utama.

Koentjaraningrat.(2002). Pengantar Antropologi Pokok-pokok Etnografi II. Jakarta: Rineka Cipta.

Murtopo, Ali.(1971). Strategi Kebudayaan.Jakarta: CSIS.

Poesponegoro, Marwati Djoened,.\& Notosusanto, Nugroho.(1993). Sejarah Nasional Jilid II, Cetakan ke-8. Jakarta: Balai Pustaka.

Reid, Anthony.(1998). Dari Ekspansi hingga Krisis, Jaringan Perdagangan Global Asia Tenggara 1450-1680. Jakarta : Yayasan Obor.

Saksono, Widji.(1998). Mengislamkan Tanah Jawa. Bandung: Mizan.

Sofwan, Ridin dkk,.(2000). Islamisasi di Jawa, Wali Songo Penyebar Islam di Jawa Menurut Penuturan Babad. Semarang: Pustaka Pelajar.

Sofwan, Ridin.(2000). Islamisasi di Jawa; Wali Songo Penyebar Islam di Jawa menurut Penuturan Babad. Jogjakarta: Pustaka Pelajar.

Sunardjo, R.H.(1983). Unang Meninjau Sepintar Panggung Sejarah Pemerintahan Kerajaan Cerbon 1479-1809.Bandung: Tarsito.

Sunyoto, Agus.(1990). Dari Ampel Dalam ke Majapahit, Surabaya: LPLI Sunan Ampel.

Syamsu, Muhammad.(1996). Ulama Pembawa Islam di Indonesia dan Sekitarnya, Cetakan I. Jakarta: Lentera. 